\title{
APPLICATION OF A GROUNDWATER MODELLING SYSTEM IN GROUNDWATER ENVIRONMENTAL IMPACT ASSESSMENT OF RIVER AND LAKE CONNECTION IN WESTERN JILIN REGION
}

\author{
QI, Q. Q. ${ }^{1}-$ XU, Y. X. ${ }^{2 *}-$ SONG, S. H. ${ }^{1}-$ ZHANG, Z. Z. ${ }^{1}$ \\ ${ }^{I}$ School of Water Conservancy, North China University of Water Resources and Electric Power, \\ Zhengzhou 450011, China \\ ${ }^{2}$ Chinese Academy of Environmental Planning, Beijing 100012, China \\ *Corresponding author \\ e-mail:15038352532@126.com \\ (Received $5^{\text {th }}$ Feb 2019; accepted $6^{\text {th }}$ Mar 2019)
}

\begin{abstract}
Whereas groundwater numerical simulation is an essential part of groundwater environmental impact analysis, the authors propose a more accurate and suitable method for identifying and predicting the groundwater environment, laying a scientific basis for groundwater environmental impact evaluation. Targeted at the river and lake connection project in Jilin Province, this paper establishes a groundwater prediction model based on the groundwater modelling system (GMS), and considers the land salinization risk posed by the variation in groundwater level after the water diversion of the project. The results show that the depth of phreatic water in each area is greater than the upper limit of ecological water level after the implementation of the project plan, leaving a small chance for soil salinization.
\end{abstract}

Keywords: groundwater modelling system, groundwater environmental, impact prediction, numerical simulation, soil salinization risk, water diversion project

\section{Introduction}

The groundwater numerical simulation has been extensively applied to groundwater environmental impact analysis (Myles, 1970; Pradeep K., 2008; Li et al., 2014a). There are mainly two equivalently effective methods for numerical simulation of groundwater flow: the finite difference method (FDM) and the finite element method (FEM) (Liang, 2014). Featuring simpler method, faster speed and higher precision, the FDM, coupled with groundwater modeling system (GMS) (Environmental modelling research laboratory, 2005), was adopted to build up a model for ground water environment impact in this research.

As an enhancement of the hydraulic connection between different waterbodies, the river and lake connection system provides a strong guarantee to the smoothness of the water cycle ( $\mathrm{Li}$ et al., 2014b). Taking the river and lake connection project in Jilin Province (Li et al., 2014c) as an example, the groundwater level was elevated to a certain extent through the diversion of groundwater to the study area. Therefore, the groundwater can be treated as an indicator in environmental impact assessment. With the aid of groundwater simulation technology, this paper predicts the variation in groundwater level before and after the leakage recharge, and analyzes the effect of the recharge on groundwater environment in light of the water level and quality, aiming to lay a scientific basis for preparation of groundwater environmental protection measures (Chao, 2008; Vishnu and Mukand, 2011).

The study area covers 9 cities and countries in western Jilin Province (Fig. 1). According to regional topographical and hydrogeological conditions, the western plains 
region in the province was selected as the simulation area, and evaluated through the analytical method and analogy analysis (Martin, 1990).

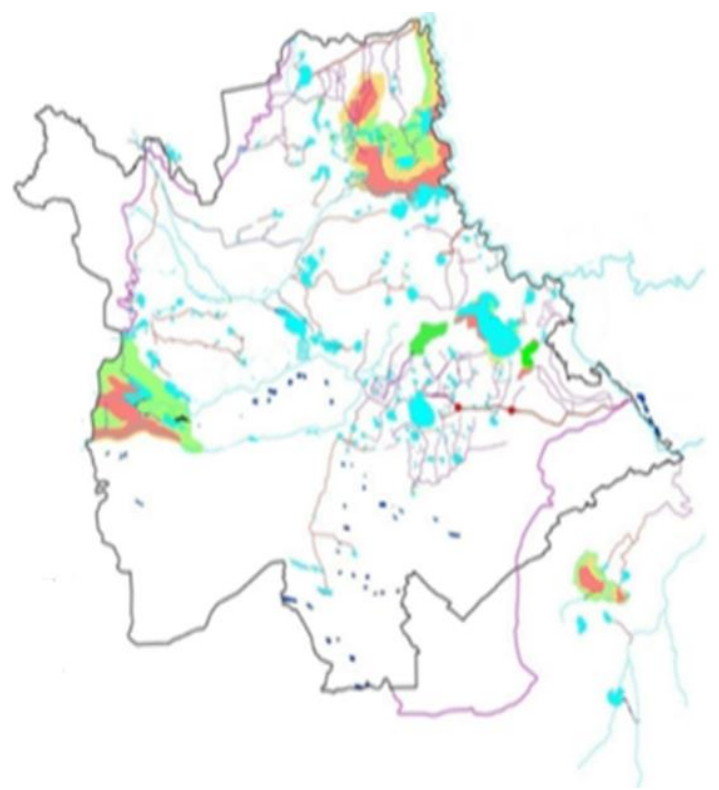

Figure 1. Jilin Lakes connection scope of groundwater numerical simulation diagram

\section{Materials and methods}

\section{Conceptual hydro geological model}

The lithology and thickness of the simulated area are different in the area, whether it is diving aquifer or confined aquifer. Therefore, the two computational aquifers are generalized as heterogeneous isotropic aquifers. The natural hydraulic gradient of the aquifer is very small and most of the areas are less than $1 \%$. The seepage is basically in accordance with the Darcy's law. The groundwater flow is limited by the accuracy of the data and is treated as a planar two-dimensional flow. The elements change over time and are generalized as unsteady.

No matter the aquifer is confined or not, the lithology and thickness in the study area are subject to different degrees of changes. Hence, both confined and unconfined aquifers are generalized as heterogeneous but isotropic aquifers. In nature, the hydraulic gradient for groundwater flow in aquifer is extremely small, which is less than $1 \%$ in most areas. Thus, the seepage basically conforms to the Darcy's law. Due to the limitations on data accuracy, the groundwater flow was treated as a 2D planar flow (Chao, 2011; Bai, 2006). Besides, it was treated as an unsteady flow because each element of the flow varies with time.

For the unconfined acquirer, the eastern rivers (the Nengjiang River and the Second Songhua River) were conceptualized as the river boundaries of groundwater in the simulation area. In southeastern and southern parts, the groundwater watershed of eastern upland plain was treated as the zero flow boundaries; the northwestern part of the simulation area was bordered by impermeable boundaries, for the bedrock of the surrounding hills were mainly volcanic rocks; In other sections in the western part of the simulation area, the boundaries were taken as the second flow boundaries; the roof 
was the water exchange boundary, and the floor was an impermeable boundary in single-layer aquifer area, and leakage boundary in double-layer aquifer area.

For the confined aquifer, in the southern part of the simulation area, the groundwater watershed was treated as the zero flow boundaries; the roof was a leakage boundary, as it was a layer of weak permeable soil, allowing the confined water to exchange with the upper phreatic water through the soil layer; the roof of the confined aquifer was generalized as an impermeable boundary, because the layer was formed up with extremely poor permeable tertiary mudstones.

Note: According to the characteristics of the regional groundwater flow field, zero flow boundaries refer to the boundaries perpendicular to water table contour lines.

\section{Numerical simulation}

\section{Simulation context}

The groundwater flow in the study area was simulated by a non-homogeneous, isotropic, quasi 3D model. The leakage amount was used to couple up the pore groundwater with porous confined water, upper pore-confined water and lower poreconfined water. The mathematical model was discretized by the GMS, the data interpolation was completed using the Kriging method, and the model was solved with the strongly implicit method. The $37,562 \mathrm{~km}^{2}$ unconfined aquifer was divided into rectangles. In total, the area was split into 36,675 grid cells in 238 columns and 258 rows. Each cell was 1,000 m long, and 1,000 m wide, covering an area of $1 \mathrm{~km}^{2}$. The meshing of the unconfined aquifer is depicted in Figure $2 a$. Total confined aquifer simulation area is $32,410 \mathrm{~km}^{2}$, split it rectangle, it is divided into 238,257 rows, altogether of grid cells, each cell is $1000 \mathrm{~m}$ long, $1000 \mathrm{~m}$ wide, with an area of $1 \mathrm{~km}^{2}$. Confined aquifer model grid shown schematically in Figure $2 b$. The model was identified and verified based on the long observation data from Jan. to Dec. 2009 and from Jan. to Dec. 2012. The stress period was set to 1 month with a time step of 6 days. Consequently, the whole simulation period was divided into 36 stress periods, each of which was subdivided into 5 time periods.
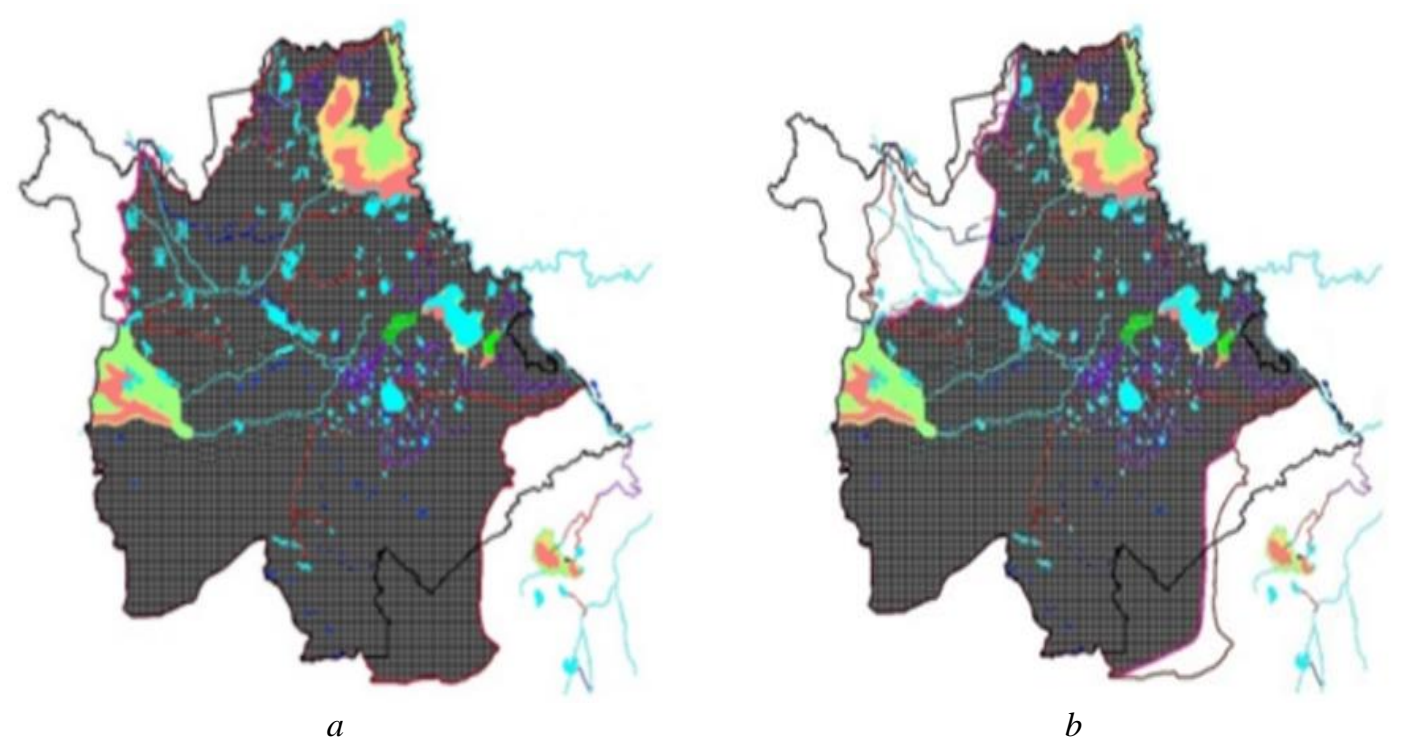

Figure 2. a Unconfined aquifer grid subdivision schemes. $\boldsymbol{b}$ Confined aquifer grid subdivision schemes 
According to the difference in topographical and hydrogeological conditions (e.g. aquifer lithology and thickness), the unconfined aquifer was classified into 21 parameter partitions, the leakage layer was divided into 5 parameter partitions, and the confined aquifer was split into 7 parameter partitions (Fig. 3a-c).

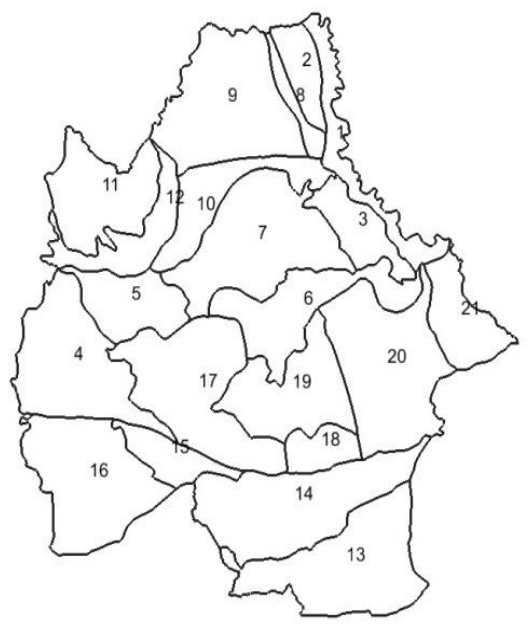

a

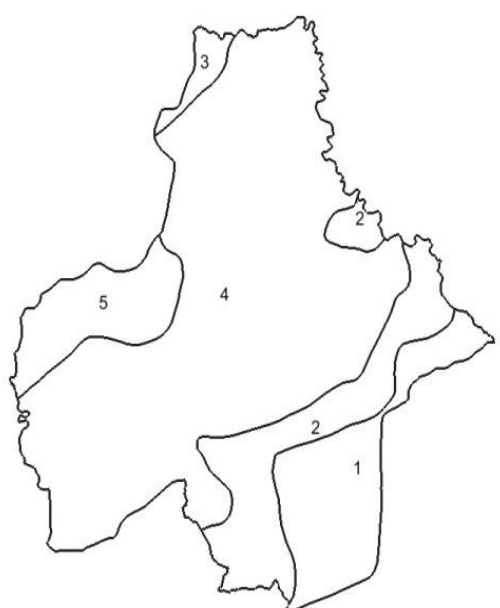

b

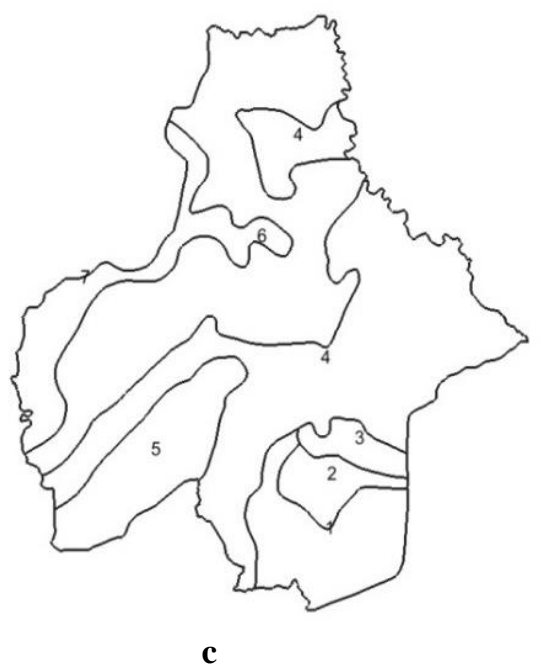

Figure 3. a Unconfined aquifer hydrogeological parameter zoning map. $\boldsymbol{b}$ The flow layer hydrogeological parameter zoning map. $\boldsymbol{c}$ The confined aquifer hydrogeological parameter zoning map

\section{Model identification}

The model was identified with the long observation data of groundwater from Jan. to Dec. 2009, which was provided by the water conservancy department of Jilin Province. The data were selected because the source sink terms of groundwater in 2009, a dry year, have little interference in model operation. Since the project is still in the planning phase, the information of the source sink terms is not accurate enough to fit the longtime series water levels at the observation points. Hence, groundwater flow field in the wet and dry periods was employed for data fitting in the simulation. The model was deemed as satisfying the accuracy requirements when the calculated flow field was in good agreement with the measured flow field. 
The source sink terms include rainfall infiltration recharge, the side run-off recharge, irrigation infiltration recharge, evaporation discharge of phreatic water, artificial exploitation amount, and river course seepage and discharge. The initial groundwater level was identified through processing these terms. According to the water levels monitored in 129 phreatic water monitoring wells and 107 confined water level monitoring wells in and around the simulation area, the initial flow fields of confined water and phreatic water in the identification period were acquired through the interpolation via the Kriging method (Mazzia and Puttii, 2002) in the GMS software (Fig. $4 a$ and $b$ ).

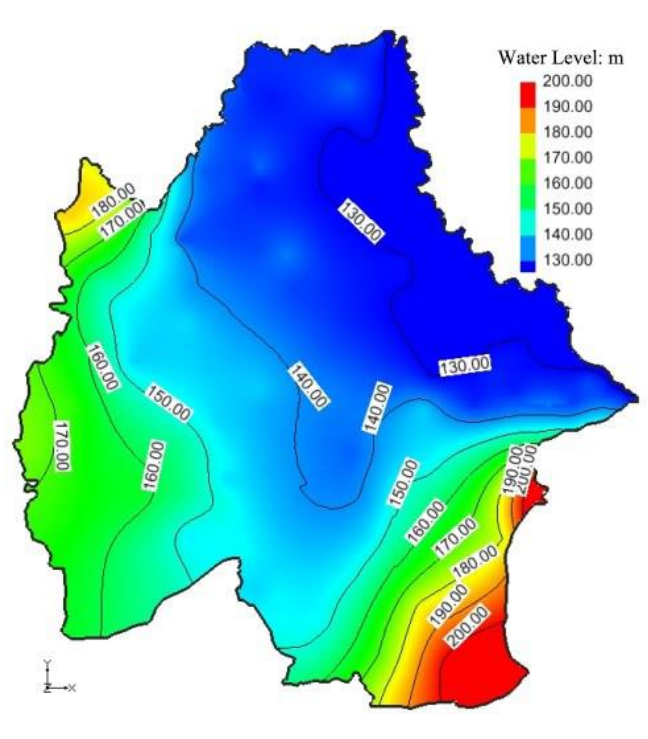

$\mathbf{a}$

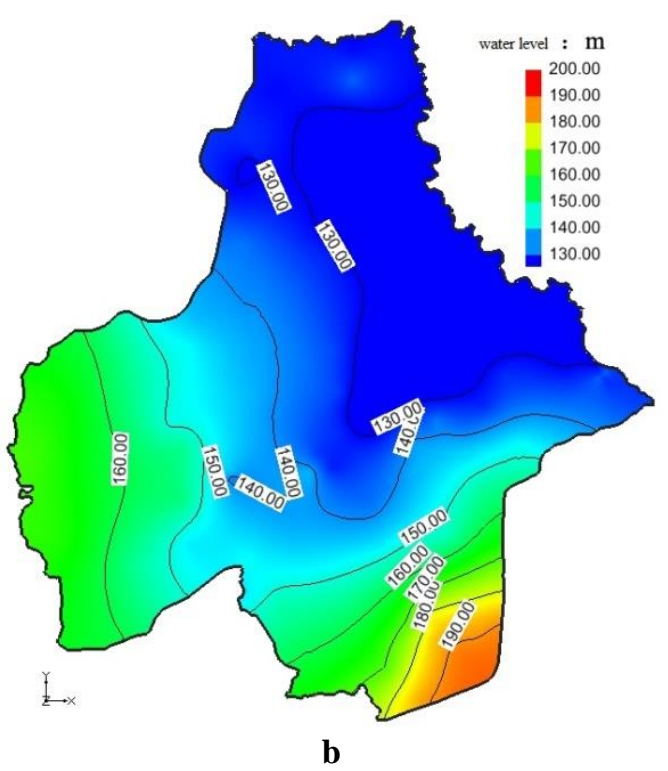

b

Figure 4. a Identification phreatic groundwater the initial flow chart. $\boldsymbol{b}$ "Zero" forecast period phreatic groundwater the initial flow

\section{Results and discussion}

After the source sink terms were inputted, the model was run to the end of the simulation period to get the calculated water level. With all things being considered, the groundwater level in the unconfined aquifer was basically stable or slightly declining under the Plan Zero, leaving little chance for soil salinization.

Based on the groundwater flow field prediction under the Plan Zero, the groundwater flow field was predicted considering the additional leakage recharge resulted from the implementation of the river and lake connection plan, and compared with the simulated results under the Plan Zero. The main source sink terms under the connection plan were consistent with those under the Plan Zero. Based on the mean annual calculated results, the additional leakage recharge was assigned to the model in light of the specific engineering plan. The simulation period lasted from Jan. to Dec. 2013. The stress period was set to 1 month with a time step of 6 days. Consequently, the whole simulation period was divided into 216 stress periods, each of which was subdivided into 3 time periods. As the model prediction plan was the same to the Plan Zero from 2013 to 2020, the authors mainly compared the variation in groundwater flow field in 2030 after the project implementation (Fig. 5). As shown in the prediction of groundwater flow field, the groundwater flow field under the project plan was basically the same with that under 
the Plan Zero; the piedmont in the western part and the groundwater shed in the southeastern part still had relatively high groundwater level and large hydraulic slope; the groundwater generally flew from the southwest to the northeast, mainly through the channels of the Nengjiang River and the Second Songhua River.

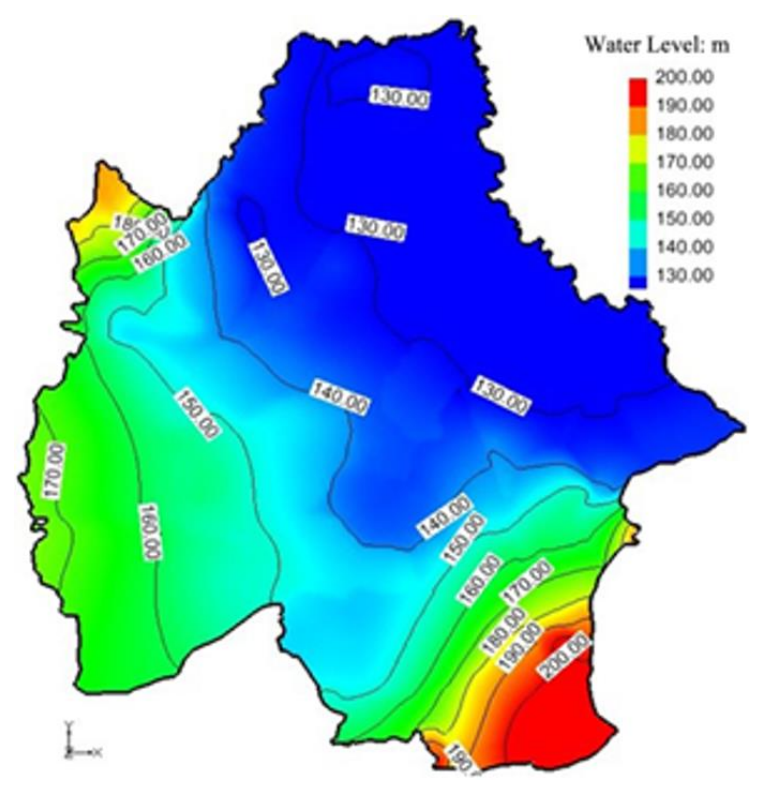

Figure 5. Predicted flow field of unconfined groundwater

According to the model prediction results under the connection plan, the regional groundwater level after the project implementation was higher than that in Plan Zero thanks to the increase in leakage recharge. Under the joint effect of growing groundwater exploitation and other factors, the phreatic water level continued to decline in 2013-2030 in core plate A; the groundwater level in core plate B kept falling in 20132020, but rebounded in 2021-2030 to a level lower than the initial level; the phreatic water level in core plate $\mathrm{C}$ and other edge plates remained stable in 2013-2030. Table 1 displays the variation in phreatic water level of each area after implementing the connection plan, and compares the level with the ecological water level.

Table 1. Plan after the implementation of the change of regional groundwater level and ecological water level of contrast

\begin{tabular}{c|c|c}
\hline Area & $\begin{array}{c}\mathbf{2 0 1 3 - 2 0 3 0} \\
\text { Range of water level }(\mathbf{m})\end{array}$ & $\begin{array}{c}\mathbf{2 0 1 3 - 2 0 3 0} \\
\text { Fluctuation rate (m/a) }\end{array}$ \\
\hline A core plate $(50,136)$ & -1.8 & -0.1 \\
B core plate $(113,176)$ & -0.9 & -0.05 \\
C core plate $(144,31)$ & 0.3 & 0.017 \\
Others $(211,108)$ & 0.1 & 0.006 \\
Area & Water depth $(\mathrm{m})$ & Ecological water level (m) \\
A core plate $(50,136)$ & $5.8-7.8$ & $1.88-5.17$ \\
B core plate $(113,176)$ & $3.7-5.43$ & $2.30-5.09$ \\
C core plate $(144,31)$ & $2.39-3.96$ & $2.35-4.87$ \\
Others $(211,108)$ & $4.26-5.24$ & $2.35-4.87$ \\
\hline
\end{tabular}


As can be seen from the above table, the depth of phreatic water in each area is greater than the upper limit of ecological water level after the implementation of the project plan, leaving a small chance for soil salinization. However, dynamic monitoring should be applied in shallow groundwater areas to control the groundwater level within a reasonable range.

\section{Conclusion}

The river and lake connection project may bring changes to the groundwater level and quality (Mazzia and Puttii, 2007). Its influence on groundwater environment mainly attributes to the leakage recharge of the diversion water. Since the water is diverted from eastern rivers with much lower degree of mineralization than the groundwater, the leakage recharge will not increase the degree of mineralization of ground water, leaving no adverse effect on groundwater salinity variation.

With the groundwater numerical simulation technology, this paper simulates and analyzes the variation in groundwater flow field and water level of the simulation area. Only two conditions were taken into consideration: Plan Zero and the connection project plan. The prediction results show that, under the connection plan, the regional groundwater level after the project implementation was higher than that in Plan Zero thanks to the increase in leakage recharge. Under the joint effect of growing groundwater exploitation and other factors, the phreatic water level continued to decline slightly in core plates $\mathrm{A}$ and $\mathrm{B}$, while that in core plate $\mathrm{C}$ and other edge plates remained stable; the depth of phreatic water in each area is greater than the upper limit of ecological water level after the implementation of the project plan, leaving a small chance for soil salinization.

Acknowledgements. This paper is funded by the High-Level Talent Introduction Plan of North China University of Water Resources and Electric Power (Grant No.: 2013038), Support Program for Young Science and Technology Innovation Talents of North China University of Water Resources and Electric Power (Grant No.: 70500), Water Conservancy Research Project of Guizhou Provincial Water Resources Department (Grant No.: KT201503) and Special Public Welfare Industry Project of Chinese Ministry of Water Resources (Grant No.: 201401041).

\section{REFERENCES}

[1] Bai, Y. M. (2006): Research on Groundwater Regime in the Western Jilin Province. The University of Jilin, Jilin Sheng.

[2] Chao, D. (2008): Research on the Assessment and Sustainable Utilization of Groundwater Resources in Shuangcheng City. - The University of Jilin, Jilin Sheng.

[3] Chao, D. (2011): Research on Real Time Groundwater Quality Prediction Model of Lower Liao He Plain. - The University of Jilin, Jilin Sheng.

[4] Elmansour, A. A., Elseed, E. G. (2018): Groundwater dynamics in Ennuhud Basin, Kordofan Region, Sudan. - Environmental and Earth Sciences Research Journal 5(4): 94100.

[5] Fu, X. G., Tang, Z. H., Lv, W. B., Wang, X. M., Yan, B. Z. (2018): Exploitation potential of groundwater in Yangzhuang Basin, China under recharge enhancement. - International Journal of Heat and Technology 36(2): 483-493. 
[6] Li, L. J., Wang, Y. L., Hu, J. M., Ma, L., Zhao, Y. N., Chen, C. Y., Wang, H. Y., Yu, Q. H., Sun, C. (2014a): Application of GMS in groundwater environment impact assessment. - Jilin Geology 33(4): 73-74.

[7] Li, Y. Y., Huang, H. J., Li, Z. L., Wang, Z. G., Chen, M. (2014b): Practical experience and development trend of the interconnected river system network, South-to-North. Water Transfers and Water Science \& Technology 12(4): 81-85.

[8] Li, Y. Y., Li, Z. L., Huang, H. J., Wang, Z. G., Chen, M. (2014c): Analyzing the evolution of the interconnected river system network and driving factors. - Resources Science 36(6): 1152-1157.

[9] Liang, Z. (2014): Study on the Eco-Economical Regionalization in the West of Jilin Province. - The University of Jilin, Jilin Sheng.

[10] Martin, K., Jackson, J. L., Whittemore, D. O. (1990): An integrated approach to identifying the salinity source contaminating a ground-water supply. - Ground Water 28(2): 207-214.

[11] Mazzia, A., Puttii, M. (2002): Mixed-finite element and finite volume discretization for heavy brine simulations in groundwater. - Journal of Computational and Applied Mathematics 14(7): 191-213.

[12] Naik, P. K., Tambe, J. A., Dehury, B. N., Tiwari, A. N. (2008): Impact of urbanization on the groundwater regime in a fast-growing city in central India. - Environmental Monitoring and Assessment 661(7): 84-89.

[13] Parsons, M. L. (1970): Groundwater thermal regime in a glacial complex. - Water Resources Research 6(6): 1701-1711. 